Tersedia Online di http://journal2.um.ac.id/index.php/jmsp/

ISSN Online : 2541-4429

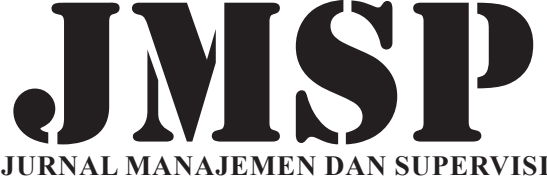

PENDIDIKAN

\title{
PENINGKATAN KUALITAS PELAYANAN PRIMA DALAM BIDANG ADMINISTRASI PESERTA DIDIK MELALUI APLIKASI SMART SOLUTION
}

\author{
Abd Munif \\ SMK Negeri Mojoagung, \\ Jalan Veteran 66 Mojoagung Jombang Jawa Timur Indonesia \\ abd.munif63.am@gmail.com
}

\begin{abstract}
Tracking diploma documents is still experiencing difficulties, because the documentation system is still manual. Mojoagung Jombang Vocational School graduated 475 students on average each year, so the diploma documentation had over capacity if the documentation system was carried out manually. This study aims to create a computer-based diploma documentation system, streamlining the search for diploma documents and making certificates of diploma replacement. Analysis of the findings was conducted using the ADDIE model development research method. The result of the smart solution application that has been implemented since 2018 is that the search time is shorter, which is 15 minutes of service, able to print the required letter documents automatically. The smart solution application has provided convenience for both school administration staff and school clients. So that it can improve the excellent service of students' administration.
\end{abstract}

Keywords: quality, excellent service, application, smart solution

\begin{abstract}
Abstrak: Pelacakan dokumen ijazah selama ini masih mengalami kesulitan, karena system dokumenasinya masih manual. SMKN Mojoagung Jombang rata-rata setiap tahun meluluskan 475 siswa, sehingga dokumeasi ijazah mengalami over capasitas jika sistem pendokumentasiannya dilakukan secara manual. Kajian ini bertujuan untuk membuat sistem dokumentasi ijazah berbasis komputer, mengefisienkan pencarian dokumen ijazah dan pembuaan surat keterangan pengganti ijazah. Analisis temuan dilakukan dengan metode penelitian pengembangan model ADDIE. Hasil aplikasi smart solution yang sudah diterapkan sejak tahun 2018 adalah waktu pencarian mejadi lebih singkat yaitu 15 menit perlayanan, mampu mencetak dokumen surat yang dibutuhkan secara otomatis. Aplikasi smart solution telah memberikan kemudahan baik bagi staf administrasi sekolah maupun klien sekolah. Sehingga bisa meningkatkan pelayanan prima administrasi peserta didik.
\end{abstract}

Kata Kunci: kualitas, pelayanan prima, aplikasi, smart solution

Sistem pelayanan merupakan suatu kegiatan atau urutan kegiatan pada suatu usaha yang dilakukan oleh seseorang atau kelompok orang maupun suatu instansi tertentu untuk memberikan bantuan dan kemudahan pada masyarakat yang mempunyai kepentingan dalam organisasi itu dalam rangka mencapai tujuan sesuai dengan aturan pokok dan tata cara yang telah ditetapkan. Penjelasan tersebut meyatakan bahwa suatu pelayanan pada dasarnya melibatkan dua pihak yang saling berhubungan yaitu organisasi pemberi pelayanan disatu pihak dan masyarakat sebagai penerima pelayanan dipihak lainnya. Jika organisasi mampu memberikan pelayanan yang optimal dan memenuhi tuntutan dari masyarakat, maka dapat dikatakan organisasi tersebut telah mampu memberikan pelayanan yang memuaskan.

Kepuasan pelanggan merupakan indikator dari keberhasilan atas pelayanan yang telah diberikan. Demikian pula dalam bidang pendidikan, pemberian pelayanan jasa pendidikan kepada para peserta didik sebagai pelanggan utama dalam sistem persekolahan sebagai suatu keniscayaan yang harus diperhatikan. Hal ini sejalan dengan hasil penelitian Jaya dan Soetopo (2007), yang menyatakan bahwa terdapat hubungan yang singnifikan antara kualitas jasa pendidikan dengan kepuasan peserta didik di 
Jurusan Administrasi Pendidikan Universitas Negeri Malang. Hasil penelitian lainnya oleh Sumarsono (2012) bahwa faktor yang paling dominan mempengaruhi kepuasan peserta didik adalah kualitas layanan yang diberikan oleh staf pegawai laboratorium, artinya kompetensi staf pegawai laboratorium menjadi kunci dari kepuasan peserta didik. Berdasarkan kajian empirik dari hasil penelitian tersebut dapat diambil suatu kesimpulan bahwa, mutu atau kualitas layanan akan mempengaruhi dan atau berdampak pada kepuasan.

Sekolah Menengah Kejuruan (SMK) Negeri Mojoangung Kabupaten Jombang, berupaya secara terus menerus berbenah diri untuk memberikan pelayanan yang optimal kepada seluruh stakeholders. Layanan yang diberikan TAS (Tenaga Administrasi Sekolah) SMKN Mojoagung meliputi bidang administrasi umum, administrasi peserta didik, administrasi kepegawaian, administrasi keuangan, administrasi sarana dan prasarana, administrasi perpustakaan, administrasi bisnis center, administrasi koperasi siswa, administrasi humas dan adminitrasi kurikulum.

Kajian ini mengkhususkan pada pelayanan dibidang administrasi peserta didik, mengingat peserta didik dan alumni merupakan steakholders utama sekolah. Upaya pemberian layanan yang berkualitas atau layanan prima yang dilakukan oleh SMKN Mojoagung, salah satunya melalui layanan administrasi peserta didik berbasis digital. Sebelum adanya pembenahan atau perbaikan dalam kualitas layanan administrasi peserta didik, pelayaan administrasi peserta didik masih dilakukan secara manual sehingga membutuhkan waktu pelayanan yang cukup lama yaitu 2 hari. Sistem smart solution yang digagas mampu memangkas waktu pelayanan menjadi lebih singkat yaitu 15 menit.

\section{METODE}

Penelitian tentang pengembangan smart solution dilakukan dengan model ADDIE (Analysis, Design, Development, Implementation, Evaluation). Tahapan penelitian diawali dengan menganalisis berbagai permasalahan yang dialami tenaga administrasi sekolah dalam melayani peserta didik dan alumni. Salah satunya dalam hal layanan penerbitan surat keterangan pengganti ijazah. Tahap kedua adalah mendesain aplikasi smart solution yang akan digunakan untuk mengefisienkan dan mempercepat layanan administrasi peserta didik dan alumni. Langkah ketiga adalah pengembangan dilakukan dengan cara mengembangkan gagasan dan konsep desain dalam bentuk aplikasi yang bisa digunakan. Setelah aplikasi selesai dibuat maka dilanjutkan ke tahap pelaksanaan (implement), tahapan ini sudah diterapkan dari tahun 2018 hingga sekarang. Tahap terahir adalah melakukan evaluasi atas penggunaan aplikasi smart solution. Proses evaluasi dilakukan dengan cara membandingkan layanan dengan cara manual dan dengan cara smart solution, mewawancarai staf administrasi sebagai penggua aplikasi dan peserta didik/alumni sebagai pihak yang dilayani.

\section{HASIL DAN PEMBAHASAN}

\section{Hasil}

\section{Aplikasi Smart Solution Surat Keterangan Pengganti Ijazah dan Pencarian Dokumen Ijazah}

\section{Pelaksanaan Program}

Mempercepat dan mempermudah pelayanan pembuatan Surat Keterangan Pengganti Ijazah, Surat Pernyataan Tanggung Jawab Mutlak, Surat Pernyataan Saksi serta pencarian dokumen ijazah, maka dibuatlah aplikasi Smat Solution. Aplikasi ini dapat dijalankan dengan proses mulai entry nomor Surat Keterangan kehilangan ijazah dari Polsek sampai dengan mencetak surat-surat serta dokumen ijazah yang dibutuhkan. Berikut adalah flow chart aplikasi tersebut: 


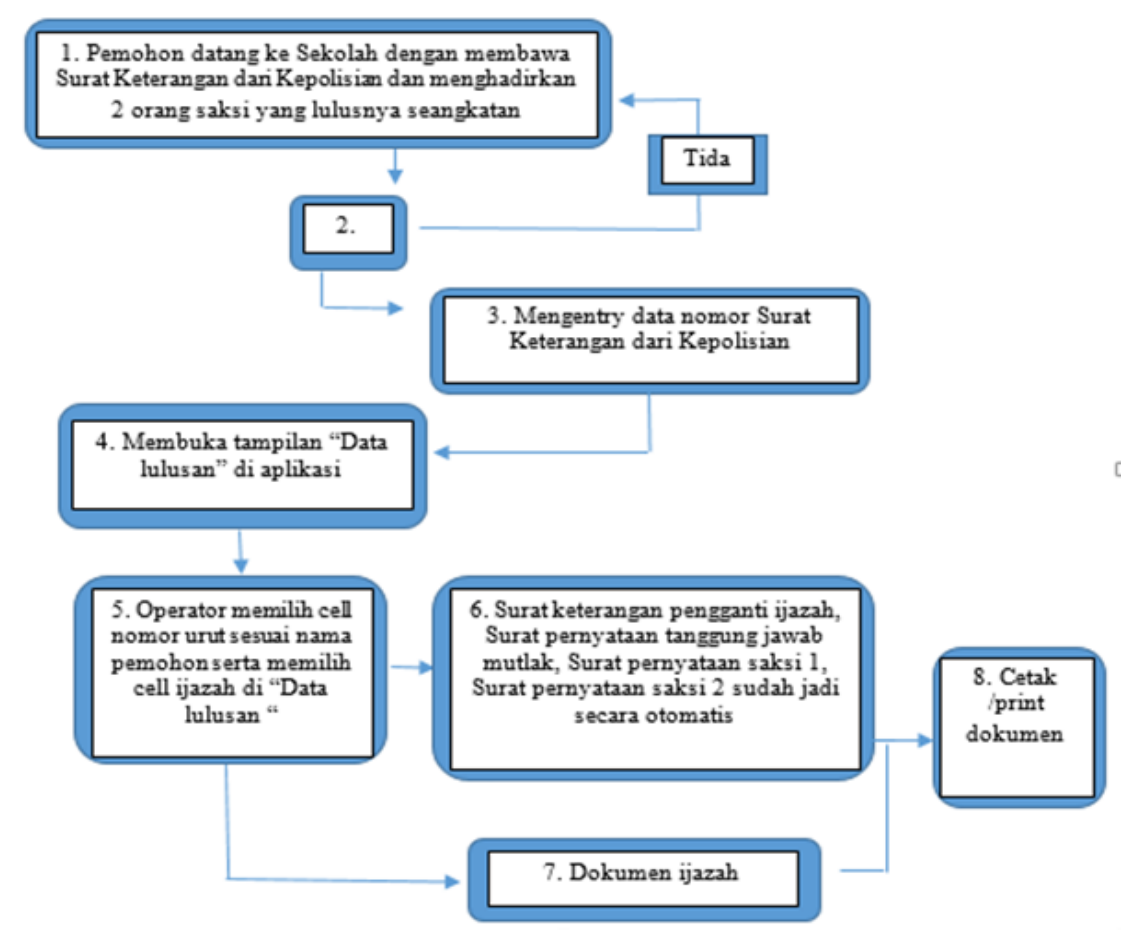

Gambar 1 Flow Chart Aplikasi

\section{Penggunaan Aplikasi Smart Solution Surat Keterangan Pengganti Ijazah}

Dalam aplikasi ini terdapat beberapa data peserta didik lulusan serta file dokumen ijazah tahun pelajaran 2016/2017, 2017/2018, yang siap diproses untuk melayani permintaan surat-surat yang dibutuhkan pemohon. Berikut adalah tampilan awal aplikasi smart solution.

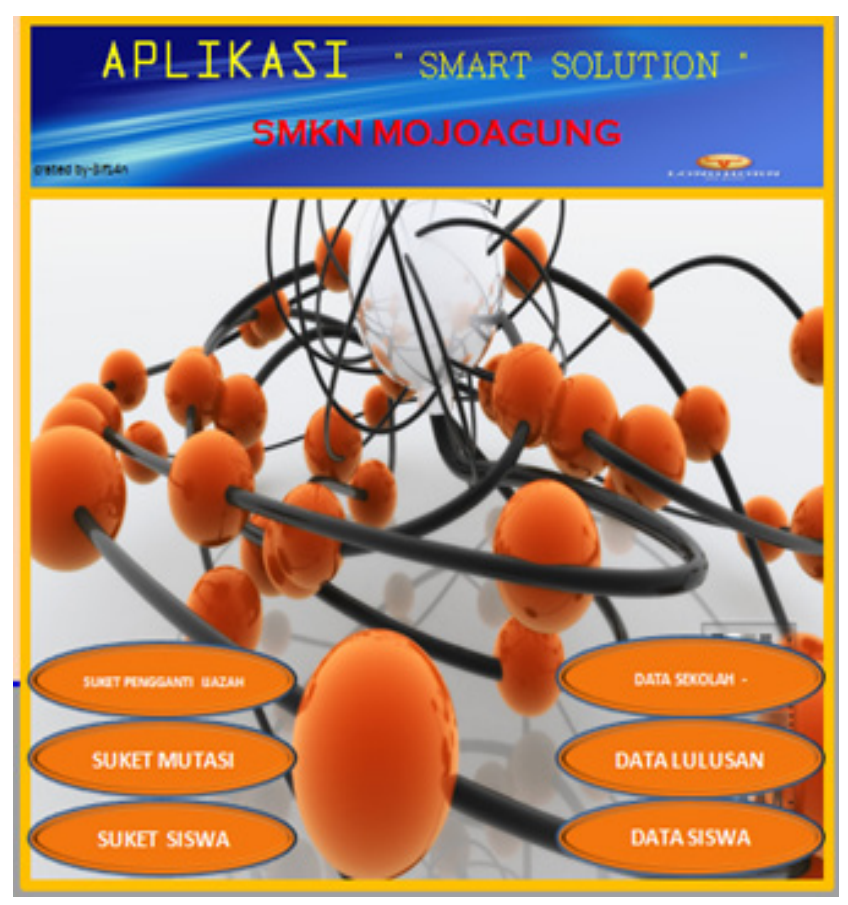

Gambar 2 Tampilan Awal Aplikasi Smart Solution 
Penjelasan gambar tersebut terdiri dari menu "suket pengganti ijazah" digunakan untuk membuka 4 (empat) naskah yang sudah diproses yaitu surat keterangan pengganti ijazah, Surat pernyataan tanggungjawab mutlak, surat pernyataan saksi 1, surat pernyataan saksi 2. Fungsinya untuk menampilkan naskah tersebut untuk dilanjutkan ke proses cetak/print. Menu "Suket Mutasi" digunakan untuk membuka 1 (satu) naskah yag sudah diproses yaitu Surat keterangan pindah/mutasi, fungsinya untuk menampilkan naskah surat tersebut untuk dilanjutkan ke proses cetak/print. Menu "suket siswa" digunakan untuk membuka 1 (satu) naskah yang sudah diproses yaitu surat keterangan siswa, fungsinya untuk menampilkan naskah naskah surat tersebut untuk dilanjutka ke proses cetak/print. Menu "data sekolah" digunakan untuk membuka data nama lembaga SMK Negeri Mojoagung, alamat sekolah, nama kepala sekolah, beserta NIP, pangkat dan jabatannya, nama kepala cabang dinas penidikan wilayah kabupaten Jombang beserta NIP, pangkat dan jabatannya, fungsinya untuk menginput data-data tersebut.

Menu "data lulusan" digunakan untuk membuka data lulusan/alumni, fungsinya untuk mencari nama dan nomor urut client yang sedang mengurus surat, mencari nama dan nomor urut 2 orang saksi, menginput data nomor surat keterangan dari kepolisian, dan untuk membuka dokumen ijazah halaman depan dan halaman belakang baik atas nama client maupun 2 orang saksi yang didatangkan. Dengan menggunakan aplikasi smart solution ini maka pelayanan permintaan surat keterangan pengganti ijazah, surat pernyataan tanggung jawab mutlak, surat pernyataan saksi dan dokumen ijazah dapat diproses dengan cepat, sehingga pekerjaan bisa dilaksanakan dengan efektif dan efisien.

\section{Aplikasi Smart Solution Surat Keterangan Mutasi Peserta Didik}

\section{Pelaksanaan Program}

Untuk mempercepat dan mempermudah pelayanan pembuatan Surat keterangan mutasi peserta didik maka diciptakan aplikasi Smart Solution. Aplikasi ini dapat dijalankan dengan proses mulai pengambilan data peserta didik yang sudah tersedia sampai dengan mencetak surat yang dibutuhkan pemohon.

\section{Penggunaan Smart Solution Surat Keterangan Mutasi Peserta Didik}

Dalam aplikasi ini terdapat data-data peserta didik yang dapat diproses secara otomatis untuk menjadi surat keterangan mutasi peserta didik sesuai dengan yang diutuhkan oleh pemohon. Berikut tampilan aplikasinya dapat dilihat pada Gambar 3.

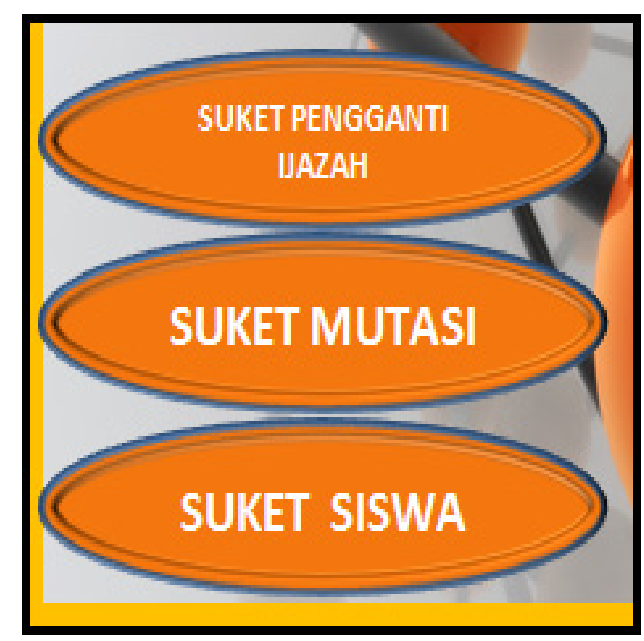

Gambar 2 Tampilan Aplikasi Membuat Surat Keterangan Mutasi Peserta Didik 
Dengan menggunakan aplikasi Smart Solution ini maka surat keterangan mutasi peserta didik dapat diproses sesuai yang dibutuhkan oleh pemohon dengan cepat dan efisien.

\section{Aplikasi Smart Solution Surat keterangan peserta didik}

\section{Pelaksanaan program}

Untuk mempercepat dan mempermudah pelayanan pembuatan surat keterangan peserta didik maka dibuatlah aplikasi smart solution, aplikasi ini dapat dijalankan dengan proses mulai mengentry data peserta didik sampai dengan mencetak surat

\section{Penggunaan Aplikasi Smart Solution Surat keterangan peserta didik}

Aplikasi ini terdapat data-data peserta didik yang dapat diproses secara otomatis untuk menjadi surat keterangan peserta didik sesuai dengan yang diutuhkan oleh pemohon. Sebagai contoh surat keterangan dapat dilihat pada Gambar 4 berikut.

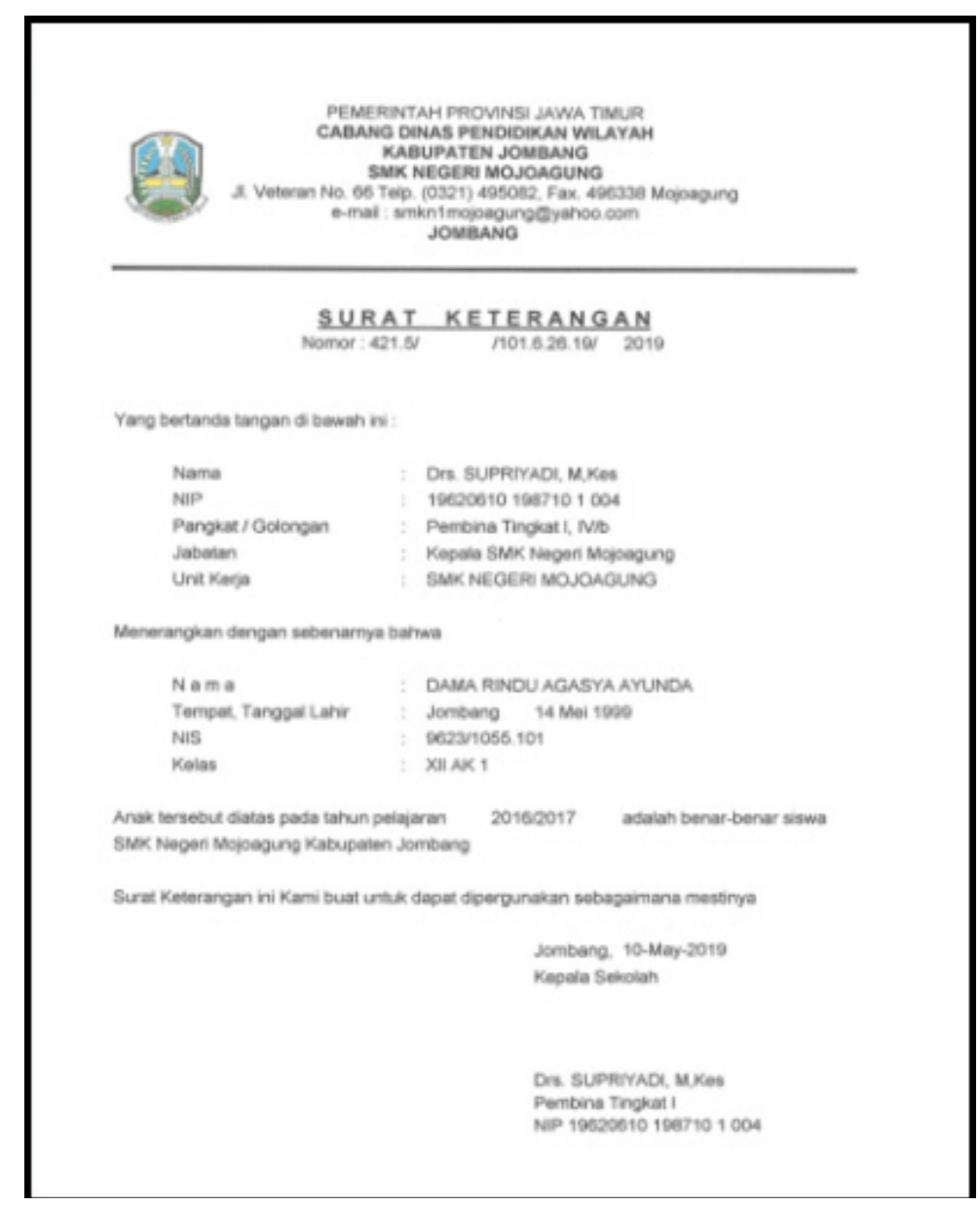

Gambar 4 Surat Keterangan Peserta didik

Dengan aplikasi Smart Solution ini maka surat keterangan peserta didik dapat diproses sesuai yang dibutuhkan oleh pemohon dengan cepat dan efisien.

\section{PEMBAHASAN}

Sekolah sebagai sistem terdiri atas komponen-kompenen yang saling terkait dan saling mempengaruhi dalam mencapai tujuan. Berbagai input mulai dari siswa, guru, biaya, serta instrumental dan environmental input lainnya harus dapat didayagunakan seefektif mungkin dalam proses transformasi, untuk menghasilkan output berupa peserta didik yang memiliki seperangkat nilai, sikap, 
pengetahuan serta keterampilan baru. Untuk mendayagunakan semua sumber daya tersebut, diperlukan administrasi dan pengelolaan sekolah yang baik. Kata 'administrasi' berasal dari bahasa Latin, " $a d$ " dan "ministrare". Ad berarti intensif, ministrare berarti melayani, membantu, dan memenuhi. Administrasi berarti melayani secara intensif(Usman, 2012). Selanjutnya, administrasi oleh Siagian (1994:3) diartikan sebagai keseluruhan proses kerjasama antara dua orang atau lebih yang didasarkan atas rasionalitas tertentu untuk mencapai tujuan yang telah ditentukan sebelumnya. Berdasarkan pengertian administrasi tersebut dapat disimpulkan bahwa administrasi adalah usaha dan kegiatan yang berkenaan dengan menyelenggarakan kebijakan untuk mencapai suatu tujuan.

Definisi administrasi sekolah oleh Zulkarnain \& Sumarsono (2018) diartikan sebagai suatu proses secara keseluruhan yang menggunakan dan mengikutsertakan semua sumber potensi yang tersedia, baik personal maupun material dalam upaya mencapai tujuan sekolah secara bersama dengan efektif dan efisien. Lebih lanjut Zulkarnain \& Sumarsono (2018) menyatakan bahwa bidang tugas yang ada di dalam administrasi sekolah antara lain mencakup: (1) administrasi kurikulum dan pembelajaran, (2) administrasi peserta didik, (3) administrasi pendidik dan tenaga kependidikan, (4) administrasi sarana dan prasarana pendidikan, (5) administrasi keuangan/pembiayaan sekolah, (6) administrasi program hubungan sekolah dengan masyarakat, (7) administrasi program bimbingan dan konseling, dan (8) administrasi persuratan dan kearsipan.

Kegiatan administrasi sekolah dewasa ini mengikuti perkembangan teknologi dan sistem informasi. Penggunaan perangkat komputer dan sistem digital menjadi suatu keniscayaan, agar kualitas administrasi sekolah semakin meningkat. TAS SMKN Mojoagung Kabupaten Mojokerto telah melakukan berbagai upaya untuk mewujudkan hal tersebut. Beberapa software aplikasi sudah diciptakan, seperti software pelayanan surat keterangan pengganti ijazah, surat keterangan mutasi, dan surat keterangan siswa aktif. Aplikasi yang diciptakan terlihat sederhana namun sangat bermanfaat dan mampu memberikan kepuasan kepada peserta didik dan bahkan staf administrasi sebagai petugas pelayanan.

Secara konseptual aplikasi yang dibuat ditujukan untuk mempermudah dan mempercepat proses pekerjaan dengan menjalankan perintah dari pengguna. Menurut Kamus Besar Bahasa Indonesia, aplikasi merupakan suatu program komputer yang dibuat untuk mengerjakan dan melaksanakan tugas khusus dari pengguna. Sedangkan menurut Winarno dan Zaki (2013) aplikasi merupakan komponen yang berfungsi sebagai media untuk menjalankan pengolahan data. Berdasarkan pengertian aplikasi di atas bisa disimpulkan bahwa aplikasi merupakan penerapan suatu sistem untuk mengolah data yang menggunakan ketentuan atau pemrograman tertentu. Tujuan menciptakan aplikasi adalah untuk membantu mempermudah berbagai macam keperluan, diantaranya untuk: mencari dokumen, membuat laporan, menginput data, dan lain-lain.

Aplikasi smart solution pada best practice ini dimaksudkan untuk mempermudah proses pelaksanaan administrasi peserta didik terkait dengan pembuatan surat keterangan pengganti ijazah, surat mutasi peserta didik, dan surat keterangan peserta didik. Melalui aplikasi ini, proses pelaksanaan administrasi peserta didik berjalan secara efektif dan efisien. Keberhasilan pembuatan dan pemanfaatan telah menunjukkan adanya kualitas layanan dan meningkatnya kepuasan klien. Kualitas pelayanan memiliki hubungan yang erat dengan kepuasan pelanggan. Kualitas pelayanan memberikan suatu dorongan kepada pelanggan untuk menjalin ikatan hubungan yang kuat dengan perusahaan. Sehingga perusahaan dapat meningkatkan kepuasan pelanggan, dimana perusahaan dapat menghilangkan pengalaman pelayanan yang masih kurang memuaskan. Kualitas pelayanan menjadi faktor yang sangat penting dalam rangka pembentukan loyalitas pelanggan.

Perhatian pada kualitas layanan pendidikan yang menekankan pada kepuasan peserta didik. Peningkatan mutu sekolah termasuk di dalamnya mutu layanan administrasi merupakan upaya-upaya yang harus dilakukan agar kepuasan peserta didik sebagai pelanggan lembaga pendidikan dapat diberikan secara optimal. Namun demikian ada beberapa masalah yang akan dihadapi oleh sekolah di Indonesia pada umumnya, antara lain rendahnya mutu layanan sekolah menjadi kendala dalam meningkatkan mutu pendidikan secara nasional, di lain pihak mutu layanan sekolah mempunyai hubungan dengan kepuasan peserta didik sebagai pelanggan sekolah. 
Pengukuran kepuasan pelanggan merupakan elemen penting dalam menyediakan pelayanan yang lebih baik, lebih efisien dan lebih efektif. Apabila peserta didik merasa tidak puas terhadap suatu pelayanan yang disediakan, maka pelayanan tersebut dapat dipastikan tidak efektif dan tidak efisien. Supriyanto (1999) mengatakan lembaga yang unggul akan selalu menjaga kedekatan dengan pelanggan serta memiliki keterkaitan dengan kualitas. Dengan demikian hubungan yang baik antara lembaga penyedia jasa (dalam hal ini sekolah) dan pelanggan (peserta didik) sangat diperlukan. Melalui hubungan tersebut sekolah dapat mengetahui harapan-harapan para peserta didik, sehingga sekolah bisa memberikan jasa yang berkualitas dan akan berdampak pada kepuasan peserta didik.

Aplikasi layanan adminitrasi peserta didik smart solution telah memberikan banyak kemudahan dan mampu mengefisienkan waktu layanan. Layanan persuratan seperti surat keterangan ijazah, dapat diselesaikan dalam waktu 15 menit. Hal ini jauh lebih cepat dibanding dengan cara manual yang bisa mencapai 2 hari. Kecepatan waktu layanan dan efisiensi waktu telah memberikan rasa puas bagi klien sekolah. Hal ini sejalan dengan pendapatnya Boone dan Kurtz (2007) yang menyatakan kepuasan pelanggan sebagai kemampuan suatu barang atau jasa untuk memenuhi atau melebihi kebutuhan dan keinginan pembeli. Dalam konteks sistem persekolahan, peserta didik merupakan pelanggan yang harus dipuaskan melalui pelayanan-pelayanan yang disediakan oleh sekolah, tidak terkecuali layanan administrasi.

Capaian kepuasan pelanggan dan kualitas layanan yang lebih baik merupakan perwujudan dari konsep pelayanan prima. Secara konseptual pelayanan prima (excellence service) merupakan suatu pelayanan terbaik, melampaui, dan mengungguli pelayanan yang diberikan oleh pihak lain atau dari pada pelayanan waktu yang lalu. Pelayanan prima juga dapat diartikan sebagai suatu pelayanan terbaik dalam memenuhi harapan dan kebutuhan pelanggan. Sedarmayanti (2009: 249) menyatakan pelayanan prima adalah pelayanan yang diberikan kepada pelanggan minimal sesuai dengan standar pelayanan (cepat, tepat, akurat, murah, ramah). Sementara itu Zulkarnain dan Sumarsono (2018) mengartikan pelayanan prima sebagai suatu aktivitas yang bertujuan untuk membantu masyarakat yang dilakukan dengan cara terbaik dan menggunakan standar pelayanan minimum sehingga hasilnya lebih dari yang diharapkan.

Meningkatnya kepuasan peserta didik dan alumni atas layanan yang diberikan TAS SMKN Mojoagung merupakan perwujudan tercapaianya tujuan layanan prima. Seperti yang dikemukakan Ismail (2010) bahwa tujuan dari pelayanan prima yaitu untuk memberikan kepuasan atau sesuai dengan keinginan pelanggan. Oleh sebab itu mutu pelayanan publik adalah kesesuaian antara harapan dan keinginan dengan kenyataan dari praktik pelayanan yang diberikan oleh organisasi publik. Demikian pula Zulkarnain dan Sumarsono (2018) menyatakan bahwa tujuan dari pelayanan prima yaitu (1) membangun kesetiaan pelanggan (customer loyality), dan (2) memberikan rasa puas dan kepercayaan pada pelanggan. Intinya adalah bahwa dengan melayani pelanggan secara prima berarti membantu pelanggan memenuhi kebutuhannya dan dilakukan dengan cara terbaik, sehingga pelanggan akan setia dalam menggunakan produk atau jasa yang diberikan oleh penyedia layanan dan mereka juga merasa puas atas pelayanan yang diperolehnya itu lebih dari yang diharapkan.

\section{SIMPULAN}

Layanan administrasi peserta didik dengan menggunakan aplikasi smart solution telah mampu mengurangi waktu layanan, dimana sebelumnya bisa sampai 2 hari, dapat diefisienkan menjadi 15 menit. Hal ini berimplikasi pada meningkatnya kualitas layanan dan kepuasan peserta didik/alumni yang dilayani. Selain itu, aplikasi smart solution juga mampu mendorong terwujudnya pelayanan prima TAS SMKN Mojoagung. Kepala sekolah, guru, peserta didik telah memberikan testimoni dari keberhasilan sistem ini. Perbaikan dan penyempurnaan sistem akan terus dilakukan agar manfaat dari aplikasi tersebut semakin tinggi. 


\section{DAFTAR RUJUKAN}

Sedarmayanti. 2009. Birokrasi, dan Kepemimpinan Masa Depan: Mewujudkan Pelayanan Prima dan Kepemerintahan yang Baik. Bandung : Refika Aditama.

Boone, L.E. \& Kurtz, D.L. 2007. Contemporary Business. South Western USA: Thomson Learning.

Ismail. 2010. Menuju Pelayanan Prima. Yogyakarta: Averrois Press.

Jaya, A. R. J. K., dan Soetopo, H. 2007. Hubungan persepsi Kualitas Jasa Pendidikan dengan Kepuasan Mahapeserta didik. Jurnal Manajemen Pendidikan. Volume 20, Nomor 2, September 2007.

Siagian, S. P. 1994. Administrasi Pembangunan Konsep, Dimensi dan Straginya. Jakarta: Bumi Aksara.

Sumarsono, R. B. 2012. Faktor yang Mempengaruhi Kepuasan Mahapeserta didik terhadap Kualitas Layanan Laboratorium. Jurnal Manajemen Pendidikan. Volume 23, Nomor 6, September 2012.

Supriyanto, A. 1999. Total Quality Management di Bidang Pendidikan. Malang: Universitas Negeri Malang. Usman, H. 2012. Manajemen: Teori, Praktik, dan Riset Pendidikan. (Edisi 4). Jakarta: Bumi Aksara Winarno, E. \& Zaki, A. 2013. Belajar Pemrograman VB6 dalam Sekejap. Jakarta: PT. Elex Media Komputindo. Zulkarnain, W. \& Sumarsono, R. B. 2018. Manajemen dan Etika Perkantoran: Praktik Pelayanan Prima. Bandung: Remaja Rosdakarya. 